\title{
Lovely Weather for Ducks?
}

By Dr. Stuart Houston

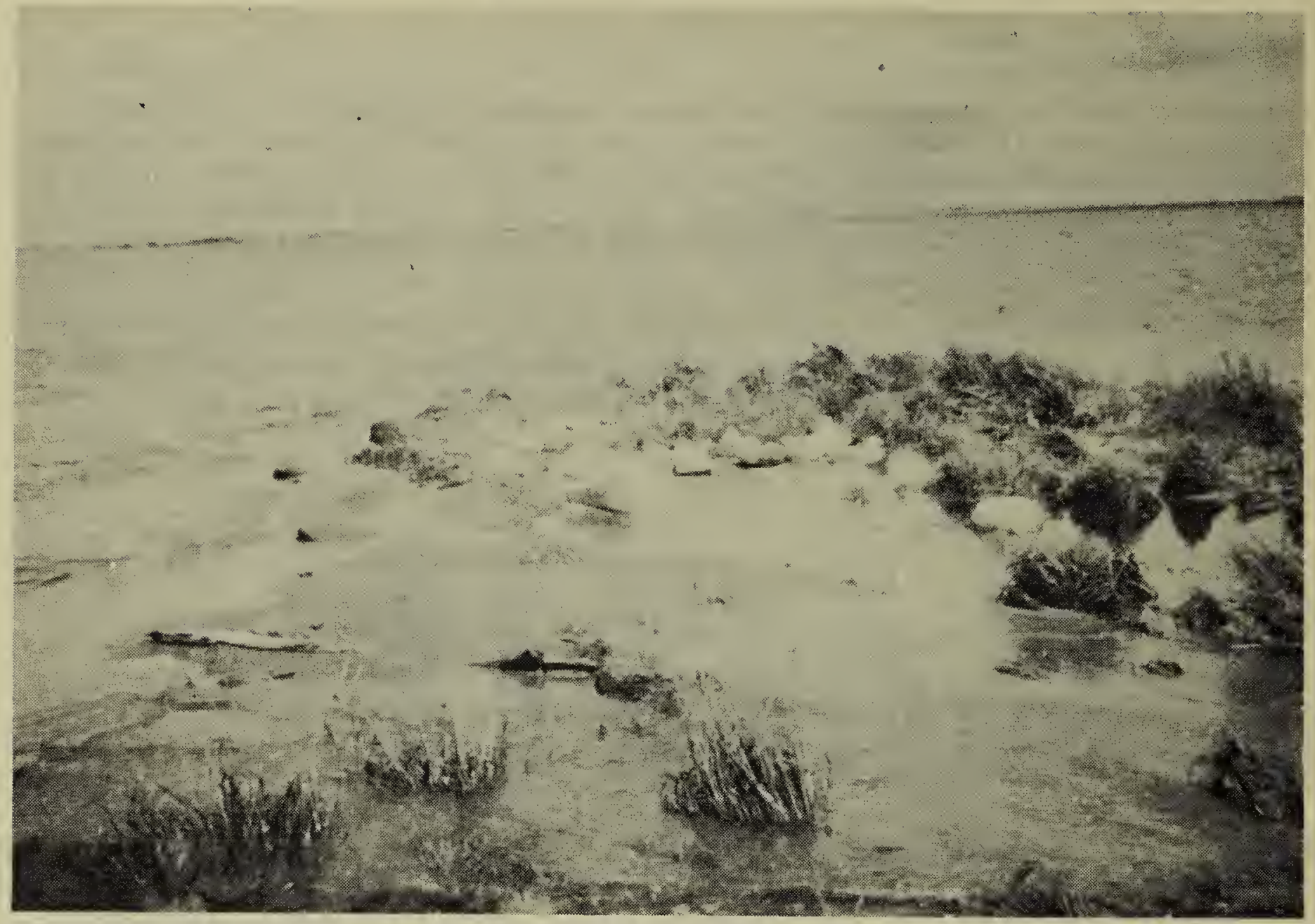

Flooded Island Opposite Imperial Beach, Last Mountain Lake, June 28, 1953. Tern eggs and young were clustered on remaining sandspit, left center. -Photo by Dr. Stuart Houston

D URING THE RAINY WEATHER, many a person remarked to me "Oh, well, it's lovely weather for ducks." But it wasn't at all. In fact, 1953 was a tragic year for the ducks and many other species of water birds in this corner of Saskatchewan.

The freezing temperatures and snowfall on May 10 th and 11 th forced many ducks to desert their nests. Ever if not deserted, many eggs were infertile and did not hatch. Later nesting attempts had to contend with the results of a precipitation twice as heavy as the average. On three occasions - during the last week in June, and again on July 10 and Aug. 2 , rains were heavy enough to cause streams, sloughs and lakes to rise suddenly and flood surrounding low areas. These floods covered many nests.

It is true that the broods have been spread over an increased water area, and that the vegetation has allowed them to hide with more success; but even allowing generously for these factors, the fact remains that we have had fewer broods of ducks in the Yorkton district than any year in the past decade. Every farmer I have talked with has confirmed my opinion.

But it was another group of birds elsewhere in the province - the colonial nesting birds at Last Mountain Lake - that were perhaps the hardest hit of all. The lake had risen several feet during the latter half of June. On June 28, the Belchers and I made a ten hour, thirty mile survey of the north end and west shores of Last Mountain Lake. We found that the island opposite Imperial Beach, usually used by the cormorants, pelicans, gulls and terns, had been flooded. The last land above water in this area was a tiny sandbar with waves washing over 
most of it. At the highest spot were a disorganized group of 34 Common Tern eggs - apparently these birds had moved their eggs from their nests to higher ground as the waters rose. There were six cute little downy terns running up and down the sandbar, while other lifeless downy forms had succumbed from being continually wet.

One mile south of this was a small rocky island. Here were 20 ringbilled gull nests, all with eggs, among the rocks. The sandy end of the island was occupied by an almost equal number of common tern nests, but these were in jeopardy, with water washing up over some of them. I suspect from the late date of these nests that perhaps the first nests had already been flooded out, and that the gulls and terns were now nesting for the second time. However, since the lake rose another foot in the month after my visit, probably this small colony was a total failure this year.

The main colonial nesting site this year was on a flat grassy island just offshore, more than 20 miles south of the usual nesting place. Here on June 28th, were 25 double-crested cormorant nests with eggs, and 11 nests with young. Five nests, now surrounded by water and splashed by waves, contained dead young. Over thirty pelicans were sitting on the island but none were nesting. I banded 91 young ring-billed gulls, 21 cormorants and 4 young marbled godwits.

When I returned to the colony August 1st, I found that the water had risen another 10 or 12 inches, covering about one-third of the previous area of the island. Only a few young cormorants were present, and they were old enough to swim away, leaving only one to band. However, I was amazed to find 35 new cormorant nests with the usual two or three eggs, none of which had hatched as yet. These nests were so extremely late that it is doubtful if many would raise young to maturity.

The only encouraging feature at Last Mountain Lake was that the higher grassy islands at the north end of the lake had heavy densities of nesting ducks. On June 28th, one island of less than one acre had a baldpate nest with 8 eggs, a gadwall nest with 9 eggs, lesser scaup nests with $10,9,10$ and 11 eggs; bluewinged teal nests with 7,7 and 8 eggs, and mallard nests with 6,8 and 7 eggs - a totai of 12 duck nests on one tiny island!

\section{Crow Chuckles}

H. M. Rayner, Ituna, Sask.

A crow pursued and harried by a kingbird or a blackbird is a familiar sight, and no one feels very sorry for the old black nest-robber. $\mathrm{He}$ doesn't need our sympathy anyway, being well able to take care of himself in most situations.

A few days ago, (this is being written in June 1953) I chanced to see Mr. Crow himself playing the kingbird role, and another bird on the receiving end. The other bird was one of the larger hawks-a marshhawk, I think.

Though we think of the crow as slow and clumsy when we compare him with a kingbird, he proved far superior to the hawk in speed and dexterity of flight. He would dive down on the hawk, giving vent to the same throaty squawks as when he himself is attacked and trying to escape.

However, the hawk didn't seem to be greatly concerned, and Mr. Crow soon tired of the game, - turned around, and went back to his nest. No doubt he indulged in some crowchuckles about this reversal of the established order, and bragged to Mrs. Crow and the family of his daring exploit.

\section{ANNUAL MEETING October 24th}

Plan to attend. 